\title{
STRATEGIES FOR TEACHING INFERENCE COMPREHENSION SKILLS TO A GRADE 8 LEARNER WHO LACKED MOTIVATION TO READ
}

\author{
Y Moopelwa and J Condy \\ Cape Peninsula University of Technology
}

\begin{abstract}
In South Africa, there is a dearth of detailed research into the challenges that high-school learners face in reading: many young adults leave school without being able to read effectively. The purpose of this study is of theoretical and educational importance because it investigates effective teaching strategies for inference-making of a Grade 8 boy who lacked reading motivation. The study is based upon an amalgam of pedagogic elements drawn from the works of Bandura, Piaget and Vygotsky. The concepts of reading comprehension, inference-making skills, teaching strategies and the impact of motivation on reading comprehension achievement are linked within the notion of social cohesion. One Grade 8 learner was purposively selected because his pre-test comprehension test results indicated his inference skills demanded particular attention. A mixed-method research approach using both interviews and observations was purposively devised for the project and deployed. Preand post-test results were analysed. He was interviewed a year later to determine whether any long-term improvements were discernible after the intervention programme. The findings suggest that, with explicit teaching, being socially engaged with the text, the learner's intrinsic motivation improved as well as his reading practices and his inference skills.
\end{abstract}

Keywords: high school learner, inference making skills, higher-order thinking skills, intervention programme

\section{INTRODUCTION}

Despite an extensive amount of research conducted into the reading practices of South African primary school learners, there is a dearth of research outlining the reading abilities, challenges and successes of high school learners. The World Bank Development Report, (2018: 3) states that it is a great injustice and a moral crisis that many young adults leave school 'without even the most basic life skills. Even if they attend school, many leave without the skills of .... [how to read] a doctor's instructions, or interpret a campaign promise...'. In the 2019 State of the Nation Address, the President of South Africa (Ramaphosa, 2019) stated that: ' ... another critical priority is to substantially improve reading comprehension ... it is possibly the single most important factor in overcoming poverty, unemployment and inequality'.

Rule and Land (2017) suggest that South Africa's dire literacy situation shows that we have '... lost the plot in the teaching of reading'. This crisis is illustrated by the poor results of the Progress in International Reading Literacy Study (PIRLS) (Howie, Combrinck, Roux, Tshele, 
Mokoena \& McLeod Palane, 2016: 70) which states that ' $78 \%$ of South African Grade 4 children were unable to read for meaning or retrieve basic information from the test to answer the simplest questions'. Table 1 shows the Grade 3, 6 and 9 results of 2017 Western Province Education Department's Systemic testing results. The South African Curriculum and Assessment Policy Document (CAPS) (Department of Basic Education, 2011a) includes the following literacy skills in the Language component: Reading and Viewing, Writing, Thinking and Reasoning and Language structure and use. This particular research study focuses upon the literacy skills of inference-making which falls within the category of 'Thinking and Reasoning'; so that these scores alone are provided.

Table 1 The results of the 2017 WCED Systemic Testing in Language

\begin{tabular}{|c|c|c|c|}
\hline Pass \% & & & \\
\hline Area Tested & Grade 3 & Grade 6 & Grade 9 \\
\hline $\begin{array}{ll}\text { Thinking } & \text { and } \\
\text { Reasoning } & \end{array}$ & 50.7 & 38.7 & 30.9 \\
\hline
\end{tabular}

These poor results correspond with a report by Zimmerman and Smit (2014: 6) which posits that (i) learners often move to secondary school unable to comprehend a simple text and that (ii) 'teachers do not maximise opportunities to develop the comprehension skills and thinking and reasoning of learners'. According to the Department of Basic Education (2014), many learners lack the ability to draw inferences from the given text. The CAPS Grades 7- 9 English Home Language (HL) and First Additional Language (FAL), (Department of Basic Education, 2011a) provide guidelines for teaching comprehension skills: the very stage at which the Grade 8 learners should be able to draw inferences from basic texts. This study is of theoretical and educational importance because it investigates effective teaching strategies for inference-making of a Grade 8 learner who lacked reading motivation.

\section{CONCEPTUAL FRAMEWORK}

This study synthesises pedagogic priorities of Bandura, Piaget and Vygotsky. The interlinking of these theories provides background information on key relations between reading motivation and comprehension achievement.

Bandura's self-efficacy theory relates to how an individual judges her or his capacity to perform a particular task: it is regarded as one of the main factors that determine motivation (Bandura, 1993; Bandura, Barbaranelli, Caprara \& Pastorelli, 1996). Bandura (1993: 118) states that: 'Those who have a high sense of efficacy visualise success scenarios that provide positive guides and supports for performance.' These cognitive functions (Bandura, 1991) include: reflective self-appraisal, self-reactions and self-regulation phenomena which are motivators for learners to become independent critical readers.

This study focused upon the case of a struggling Grade 8, 14 year old male learner, who lacked motivation to read. He was failing in his class and transitioning from childhood to adulthood. Caprara, Pastorelli, Regalia, Scabini and Bandura (2005: 72) suggest that an individual learner at high school level not only has to master his school work and 'manage major biological, educational, and social role changes but also cope with growing strains of independence.' Caprara et al. (2005) suggest that if one '... has little incentive to act or to persevere in the face of difficulties, adolescents' self-efficacy beliefs may have a negative influence throughout the course of adult life'.

Per Linguam 2019 35(3):1-15

http://dx.doi.org/10.5785/35-3-883 
Piaget's theory of cognitive development was appropriate to this study. Learner X who was 14 years old, fell within Piaget's 'formal operations stage' (Piaget, 1981), where he was beginning to 'assign himself a role and goals in social life'. Piaget states that '... students who are eager to learn have more enthusiasm for studying and learn more easily. Conversely, ... they probably owe their weakness to an affective block.' He continues to argue that 'affective factors are involved even in the most abstract forms of intelligence'. In this particular research study, Learner X had no schemata, which is a mental structure by which individuals adapt to, assimilate and organise their environment to accommodate new schemata (Wadsworth, 1989), of higher-order comprehension skills. He was in a state of disequilibrium (Piaget, 1981). Learner $\mathrm{X}$ was purposively selected to participate in this research project since he would be actively involved in developing new schemata of inference-making comprehension skills: he would be assimilating and accommodating new knowledge into his already existing schemata. It was hoped that this new information would result in behaviour that established a better sense of equilibrium.

Although Bandura's (1991) self-efficacy theory, Piaget's (1981) cognitive development theory and Vygotsky's (2011) theory of social constructivism are distinct, there are some points of overlap. In this research project, the researcher sought to move Learner $X$ to the next level of cognitive development; referring to Vygotsky's (2011) Zone of Proximal Development (ZPD) became necessary. Luria (1976: 8), who was one of Vygotsky's students, wrote: '.. consciousness is the highest form of reflection of reality ... shaped by activity and used by human beings to orient themselves to their environment, not only in adapting to conditions but in restructuring them'. Learner $X$ was being introduced to new schema and he was having to assimilate and adapt to the new learning. Vygotsky (2011: 204) states that the ZPD of the learner 'is the distance between the level of his actual development, determined with the help of independently solved tasks and the level of possible development with the help of tasks solved by the child under guidance of adults'. The researcher scaffolded, through guided practice and role modelling, the inference-making comprehension skills, so that Learner X could move to his zone of ability and independence.

\section{LITERATURE REVIEW}

This section reviews literature from relevant studies on reading comprehension, inferencemaking skills, teaching strategies and the impact of motivation upon reading comprehension achievement.

\section{Reading comprehension}

Reading comprehension is a learning process that involves how learners understand words and how the meaning attached to those words can be used to create new meaning (Schumm, 2006). This process involves acknowledging and exploiting prior knowledge, together with knowledge acquired through social interactions (Donald et al., 2014) to create new meanings. McGee and Johnson (2003) emphasise that the entire school curriculum requires learners to be able to read and understand content before they attempt to complete an assignment. The South African Curriculum and Assessment Policy Statement (CAPS) document for English Home Language (HL) and First Additional Language (FAL) states that in Grade 8, inferencemaking should count for at least $40 \%$ of formal assessment (Department of Basic Education, 2011a). This stipulation can be confirmed by observing the CAPS document for the various subjects. In the Life Sciences curriculum, it is stated that assessments must be set to cover a range of cognitive levels; including comprehension (Department of Basic Education, 2011b). 
A number of international studies have discerned that spending more time on reading and increasing reading frequency is associated with improved comprehension skills (Guthrie \& Wigfield, 1999; Gambrell, 2011). However, in South Africa, Pretorius and Klapwijk (2016: 3) have found that despite comprehension being the goal of reading, many teachers spend more time on the 'mechanical skills of decoding rather than on meaning and comprehension'. They believe that Higher Education Institutions should focus on producing knowledgeable teachers who are able to 'teach reading effectively and meaningfully' (2016: 15). Klapwijk (2011: 53) recommends that universities add 'explicit reading comprehension instruction in all teacher-training courses, and also that a research component be added to pre-service, inservice and professional development courses'.

Pretorius and Klapwijk (2016:7) reveal that in their study, primary school teachers at higher performing South African schools revealed a 'deeper understanding of reading comprehension and articulated the need to teach their learners specific strategies'. Beck and Condy (2017) concur with this statement: that deliberate instruction of higher-order comprehension skills is crucial. The focus of this current study was particularly upon the use of a variety of strategies to teach inference-making skills.

\section{Inference-making comprehension skills}

There appears to be a lack of detailed research into the teaching and learning of inference skills in South African high schools, especially at high school level. In her study, Zimmerman (2014) found that teachers in her Grade 4 study did not know how to generate higher-order questions for comprehension purposes; preferring either to follow the published questions without questioning the educational value of the questions or ask retrieval questions orally. Zimmerman (2014) suggests that teachers in the Intermediate Phase may not emphasise higher-order comprehension development because they fail to appreciate how important these skills are. Zimmerman (2014) poses the question that, if teachers do not teach these skills in the lower grades, they '.. may not have enough exposure to the type of questions needed for further development of higher-order thinking and reasoning skills'.

Internationally, Johnson and Keir (2010) state that inference-making, one of the higher-order comprehension skills, requires readers to combine text with prior knowledge (Johnson \& Keir, 2010) and '... go beyond the information that is stated explicitly' (Oakhill, Cain \& Elbro, 2015: 38). They suggest that, to encourage learners to make appropriate inferences while reading, learners should be prompted to make '.. associative links between text knowledge and prior knowledge ... getting the readers more involved in understanding and interpreting the text'. Clinton (2015) proposes that when readers can infer, they are able to connect the text to themselves or to their world by using background knowledge; creating a meaningful representation of the text. Oakhill et al. (2015) assert that '... vocabulary and inference making are mutually helpful during comprehension'. An understanding of word meanings supports inference-making and conversely in the process of inference makes readers use the context and appropriate prior knowledge to help understand unfamiliar words.

Carlson, Van den Broek, McMaster, Rapp, Bohn-Gettler, Kendeou and White (2014) mention two types of inferences: text-based and knowledge-based inferences. Clinton (2015) states that text-based inferences are necessary to understand the basic message conveyed by the text, whilst Carlson et al. (2014) say that readers connect ideas to text that was read earlier. Knowledge-based inference-making occurs when readers connect text with prior Per Linguam 2019 35(3):1-15 http://dx.doi.org/10.5785/35-3-883 
knowledge (Carlson et al., 2014). Knowledge-based inferences are necessary when the basic meaning of the text cannot be retrieved without background information (Clinton, 2015). Both types of inferences should be taught explicitly to grant learners a comprehensive or global understanding of the text. If learners are not explicitly taught inference-making, it becomes difficult for them to answer questions that require a more in-depth processing of a text (McGee \& Johnson, 2003).

\section{Reading motivation and reading comprehension achievement}

A number of learners at high school level in South Africa read below grade-level and are resistant to reading school content (Guthrie, 2008). Clinton (2015) reports on a positive relation between reading motivation and improvement in comprehension strategies, such as inference-making. He argues that learners who are motivated to read tend to engage naturally with a text which could lead to deeper understanding of the ideas within the text. Klauda and Guthrie (2015: 239) echo this finding: '.. engagement refers to the behavioural displays of effort, time and persistence in attaining desired goals'. Guthrie and Klauda (2013) posit that providing positive feedback to students assures them of success which increases their selfefficacy. For many readers, reading motivation acts as a stimulant and may lead to raised levels of reading (Logan, Medford \& Hughes, 2011). Because reading motivation is usually considered a willingness to take part in reading activities (Clinton, 2015), readers who find the discipline challenging need to be motivated in order to begin engaging freely or voluntarily with text.

Boakye (2015) found that explicit strategy instruction, goal orientation, feedback from the teacher, and providing praise have been shown to improve self-efficacy. She suggests that this affirmation should be provided on an on-going basis; providing more opportunities for success with older learners. The main research question was 'What strategies were used to teach inference comprehension skills to a Grade 8 learner who lacked motivation to read?'

Studies have shown that when learners are motivated to read, they are able to make casual inferences and comprehend the implications of the text more fully (Guthrie \& Wigfield, 1999). Boakye (2015) states that learners with high self-efficacy levels are motivated to persist for longer, put in more effort and strive to complete a given task.

\section{INTERVENTION PROGRAMME (IP)}

This section discusses the Intervention Programme (IP) that was put in place over six weeks, from 24 July to 31 August 2017, four times a week for 35-40 minutes, after school hours. The objective for the researcher who was the students' register class teacher at the school was to assist a struggling Grade 8 male learner, aged 14 (identified with the pseudonym Learner X) to improve his reading comprehension skills, especially inference-making skills. The researcher introduced Learner $\mathrm{X}$ to comprehension questions with the hope of promoting his critical thinking literacy skills.

A pre-test was administered, which included reading passages and answering questions from eight comprehension passages - varying from Grade 5 to Grade 8 passages. These texts and comprehension questions were developed by a group of Honours students based on the PIRLS study comprehension passages and trial tested before the study commenced. To test the comprehension questions, the researcher asked another Grade 8 learner, not in the same 
class as Learner X, to read one passage from the Grades $5-8$ texts, answer the questions and to comment on the task. He reported that he was comfortable with the level of texts and the wording of the questions. Table 2 is the graphical representation of the learner's pre-test results.

Table 2 Pre-test results

\begin{tabular}{|l|l|l|l|}
\hline Skill & $\begin{array}{l}\text { Number of } \\
\text { questions }\end{array}$ & $\begin{array}{l}\text { Number } \\
\text { errors }\end{array}$ & $\begin{array}{l}\text { Percent } \\
\text { errors }\end{array}$ \\
\hline $\begin{array}{l}\text { Explicitly of } \\
\text { information stated }\end{array}$ & 8 & 0 & $0 \%$ \\
\hline Inference-making & 8 & 6 & $75 \%$ \\
\hline $\begin{array}{l}\text { Linking to a past text, } \\
\text { community and world }\end{array}$ & 8 & 1 & $12.5 \%$ \\
\hline Summarisation & 8 & 4 & $50 \%$ \\
\hline
\end{tabular}

From the above results, it was evident that the skills that required intervention were 'inference-making' and 'summarisation' which showed the highest percentage of errors. This study, however, focused exclusively upon inference skills. These results correspond with the Annual National Assessment (ANA) Diagnostic report of the Department of Basic Education, (2014) which revealed that many learners lack the ability to make inferences from a given text.

Realizsng that the researcher needed to be more 'diversity literate' (Reygan, Walton \& Osman, 2018:1), she signed up for an online literacy course to identify strategies that may assist her learner. She was introduced to 'It says, I say, and so', as described in Table 3 - a strategy recommended by Johnson and Keir (2010) to set a sound foundation for generating and understanding the teaching of inference skills. The researcher combined this strategy with guided practice and modelling inference skills. The strategy functions as follows:

Table 3 A reading strategy called 'It says, I say, and so'

\begin{tabular}{|c|c|c|c|}
\hline Question & It says....... & I say........ & And so............. \\
\hline $\begin{array}{l}\text { Step 1: } \\
\text { Read the question } \\
\text { (created or } \\
\text { provided). }\end{array}$ & $\begin{array}{l}\text { Step 2: } \\
\text { Find information } \\
\text { from the text that } \\
\text { will help answer the } \\
\text { question. }\end{array}$ & $\begin{array}{l}\text { Step 3: } \\
\text { Think about what } \\
\text { you know about that } \\
\text { information. }\end{array}$ & $\begin{array}{l}\text { Step 4: } \\
\text { Combine what the } \\
\text { text says with what } \\
\text { you know to come } \\
\text { up with the answer. }\end{array}$ \\
\hline
\end{tabular}

An additional technique is suggested by Robb (2008) as an effective method to improve comprehension ability: the 'question generation' was included in the IP. This strategy involves asking questions while reading the text and encouraging the learner to become aware of how much he understood the text.

Pritchard (2009) suggests that when students are engaged and there are clear objectives for teaching and learning, effective learning is more likely to take place. Hence, the researcher developed a 'cognitive map' for the duration of the IP; to mediate, encourage and motivate the struggling Grade 8 learner. Green (2014: 29) describes the ' ... parameters of a cognitive map' as: 
- The content of the learning task - the researcher taught higher-order comprehension inference skills appropriate for a Grade 8 learner;

- The modality used to teach the task - the researcher used the 'It says, I say and so strategy' described in Table 3 , as well as deliberately asking higher-order comprehension questions;

- The phase of the teaching (input, elaboration and output) - reading of and predicting the outcomes of the texts were completed in the 'input phase'. During the 'elaboration phase', the researcher would follow Steps 2 and 3 as described in Table 3. Finally in the 'output phase' the researcher encouraged the learner to integrate the new knowledge (schema), and he was expected to offer his opinions;

- The cognitive functions - the researcher asked the learner to read the passage, connect the content to his prior knowledge (assimilation), discuss any unfamiliar vocabulary and allow the learner to offer his own opinions (accommodation); and

- The level of complexity - the researcher began using texts at a Grade 5 level and slowly increased the level of complexity till they were interacting with Grade 8 texts.

\section{RESEARCH METHODOLOGY}

A mixed-method approach, deploying a participatory-social justice design was used in this research project. Creswell and Creswell (2018: 228) state that: 'the mixed methods experimental (or intervention) design involves the researcher collecting and analysing both quantitative and qualitative data and integrating the information within an experiment or intervention... so that the personal experiences of participants can be included in the research'.

Creswell and Creswell (2018: 230) state that a 'participatory-social justice design is used to give voice to participants and collaborate with them in shaping the research and to build evidence from both quantitative and qualitative data'. In this study, the researcher, using a six-week IP, embedded a pre-test to assess Learner X's Grade 8 knowledge of higher-order comprehension skills and to develop an 'explanatory sequential design' (2018: 228). During the sixth week, the researcher used the same post-test to 'follow up on the experimental outcomes' (2018: 228).

The research was conducted at a public high school located in Cape Town. On average there are approximately 700 learners in the school, with an average number of 22 learners per class. This selected school falls under the category of a Quintile 5 school which 'is a system of proportional funding linked to the financial status of schools and learners'. Quintile 5 schools receive the least funding from government (Gower, 2008: 15). The majority of learners are drawn from affluent homes but there are some learners from low-income areas from various so-called 'townships' around the Cape Town metropole.

The researcher purposively selected a Grade 8 learner whose performance was below average in his Home Language (HL) and First Additional Language (FAL) which negatively impacted his knowledge of higher-order comprehension skills. The learner's language teacher and his parents were included as part of the sample. The parents were included in the sample in order to assess and comprehend Learner X's family's reading culture. 
To 'elicit views and opinions from the participants' (Creswell \& Creswell, 2018: 187) interviews and observations, of the learner's critical reading comprehension progress, and his levels of engagement and motivation, were used to collect data during the six-week IP. Six months after the IP, the researcher conducted a face-to-face interview with the learner, now in Grade 9 to gather further information in the learner's natural setting (Creswell \& Creswell, 2018), and to explore how the IP had impacted upon his inference skills.

This researcher attempted to 'develop a complex picture' of the research question which she sought to answer (Creswell \& Creswell, 2018: 182). She drew upon multiple perspectives, both qualitative and quantitative data which were inductively analysed. Henning, Van Rensburg and Smit (2004: 127) state that throughout the research process researchers '... constantly reflect on the impressions, relationships and connections while collecting the data'. She divided the data into '... smaller more meaningful units'. The data collected from the interviews and observations were colour-coded to enable the researcher to retrieve and organise data that was associated with particular themes (Maree, 2007).

Written permission to conduct the research was received from the university where the researcher was studying, the Western Cape Education Department, the school principal, the teacher involved and the parents. In consultation with the parents, Learner X signed a consent form to participate in the study (Martella, Nelson, Morgan \& Marchand-Martella, 2013). To ensure confidentiality, the school's name was not mentioned in the study and the learner was assigned a pseudonym (Martella et al., 2013).

\section{FINDINGS AND DISCUSSION}

The purpose of this research paper was to investigate effective teaching strategies for improving the inference-making skills of a Grade 8 learner who lacked reading motivation. According to the post-test results in Table 4, the learner improved in inference-making yet the results for summarisation remained unchanged. There was a decline in his comprehension skill for linking text to a past text, community and world: this skill was not included in the IP.

Table 4 Pre-test and post-test results

\begin{tabular}{|l|l|l|l|}
\hline Comprehension skill & $\begin{array}{l}\text { Pre-test } \\
\text { errors }\end{array}$ & $\begin{array}{l}\text { of } \\
\text { errors }\end{array}$ & \% \\
\hline Retrieve explicitly stated information & 0 & 0 \\
\hline Inference-making & 75 & 50 \\
\hline $\begin{array}{l}\text { Linking text to text, community and } \\
\text { world }\end{array}$ & 12.5 & 25 \\
\hline Summarise a piece of text & 50 & 50 & \\
\hline
\end{tabular}

The results of the pre- and post-tests, researcher's observations, interviews with the learner's current language teacher, his parents and with Learner $\mathrm{X}$ a year later were compared. After the results were inductively analysed, two themes emerged:

- Explicit teaching of comprehension skills; and

- Self-efficacy and reading motivation. 
Each theme will be discussed in more detail.

\section{Explicit teaching and scaffolding of comprehension skills}

Prior to the commencement of the IP, the researcher provided feedback from the pre-test results to Learner X. During the feedback session, he revealed that he had no knowledge of the word 'inference'.

I do not remember hearing the word inference in my English classes, even in primary school.

This finding was echoed by the language teacher's response to an interview question about explicit teaching of inference:

I don't think it (inference making) can be taught, I don't know how you teach a child to infer.

This finding aligns with Mudzielwana (2013) who found in her study that there is '.. no evidence of teacher's modelling during the teaching of comprehension strategies'. Pilonieta and Medina (2009) as well as Pretorius and Currin (2010) state that many learners proceed through to secondary school with minimal comprehension skills due to teachers' neglect of comprehension instruction.

During the IP, the researcher was of the opinion that Learner $X$ was struggling to adjust the new knowledge of inference-making into his existing schema and 'zone of ability' (Piaget, 1981, Vygotsky, 2011: 208). The following observation was noted:

The learner struggles to differentiate between explicitly retrieving information from text and inference questions. He expects that answers must be taken directly from the text.

Six months later, Learner $\mathrm{X}$ was again interviewed by the researcher, to explore how the IP had impacted upon his English learning in his Grade 9 class. The conversation went as follows:

Researcher: We did a lot of activities for teaching 'inference skills'. Do you feel more confident now after having done these activities?

Learner: Ja, at that time I did not even know what it was.

Researcher: When you read a passage, your teacher stopped and asked questions how did you find this strategy - did you like it and say - why - or did you not like it and say why?

Learner: $\quad$ I felt it was easier because the passage that you had read from would be fresh in your mind so it would be easy to answer questions as you are reading.

The use of scaffolding, through direct instruction and modelling, enabled the researcher to provide directions, and to structure the learning process in a way that kept Learner $\mathrm{X}$ constructively engaged throughout the intervention process. Piaget (1981) posits that such a learner becomes enthusiastic to learn and understand what he is learning, and starts to 
assimilate and accommodate the new schemata, slowly gaining a state of equilibrium. These social constructions of abstractions such as inference-making were mediated for Learner $\mathrm{X}$ on how to be and how to think (Vygotsky, 2011: 208).

\section{Self-efficacy and reading motivation}

At the beginning of the IP, the researcher noted that Learner X delayed starting to read the given comprehension passage. He believed that he could not read correctly. He narrated:

I do not like reading when there is someone listening because I am bad ... and it is embarrassing. And sometimes I just read to finish quickly especially in class when my classmates are laughing at how I say some words.

During the parent interview, the mother narrated that her child does not like reading:

Learner X [pseudonym] does not like reading at all, we have to push him as his parents. If you push him he will try, he needs follow ups every time.

To understand this lack of enthusiasm to read, the researcher incorporated Bandura's (1993) theory of self-efficacy which refers to an individual's belief that they are capable of performing a particular task. When an individual's self-efficacy is low, the subject believes that she cannot perform the task '... and they dwell on the many things that can go wrong' (Bandura, 1993: 118). It was obvious that the learner's self-efficacy in reading was low initially, which resulted in a lack of motivation to read: he lacked perseverance and displayed resilience towards these difficult tasks (Bandura et al. 1996). Together these two issues negatively impacted upon his ability to comprehend texts. As a result, he would at first only scan for phrases that appeared in the questions and try to find the answers in the text. The researcher wrote on her observation schedule:

The learner takes time to read the passage, the researcher has to remind him to start reading. Some of the answers are not related to the paragraph text where reference should be made. It appears that the learner is not fully engaging with the text, he scans it to look for phrases and words that appear in the questions.

The researcher observed that the learner was neither comfortable nor confident when reading aloud in front of his teacher. He rushed through some of the paragraphs which were significant for him to comprehend the passage. He often became demotivated and gave up reading altogether. In her study, Boakye (2015) confirms a positive relation between selfefficacy and reading proficiency. Clinton (2015) identifies a positive relation between reading motivation and the ability to generate inferences as necessary for higher-order reading skills.

The fact that this learner was not motivated to read, encouraged the researcher to help improve his self-efficacy and to devise a cognitive map to guide her teaching: she encouraged him to proceed with reading, regardless of the errors he made and then re-read each paragraph to allow for an opportunity to correct the errors. After re-reading a paragraph successfully, and praised by the teacher, the learner appeared less anxious and advanced to the next paragraph without delay. Reading, according to Boakye (2011), is a multifaceted skill involving social, affective and cognitive processes. This self-efficacy building strategy was focused on exploiting his actual experience and extant knowledge (Bandura, 1993; Boakye, 2015). His successful attempts to read the first paragraph without giving up made him realise that he was within his zone of ability to read (Vygotsky, 2011: 208) and this new Per Linguam 2019 35(3):1-15 
awareness motivated him to read the rest of the comprehension passage. He was beginning to self-regulate his own learning experiences; he was learning to monitor his own progress, and acted on his beliefs (Bandura, 1991).

In motivating reading, the class teacher did not seem to have any strategies in place that could be used to motivate and assist struggling readers as suggested by the following interview excerpt:

\section{Encouraging reading is one of the main things we always discuss at parent- teacher evenings and the best way to improve a child's English is to encourage them to read.}

The class teacher did not provide any clear, practical strategies to motivate reading. Mayer (2008) encourages teachers to create learning environments in which learners can realise that whether they succeed or fail depends on the amount of effort they have put in and not solely on their ability.

\section{CONCLUSION AND RECOMMENDATIONS}

The World Bank Report (2018) states that many learners around the world learn comparatively little at school. This statement was true of this high school learner: despite being in Grade 8, he admitted to never having heard the word 'inference'. The two lessons learnt from this unique study are invaluable since there is little empirical research in this particular area of teacher strategies to develop comprehension skills of thinking and reasoning with high school learners.

Despite the inference-making scores showing a slight improvement on the post-test, Learner $\mathrm{X}$ began to engage critically with texts. During the six-week IP, using the cognitive map with the aim of mediating a positive self-efficacy, the learner was able to correct his own reading fluency and made fewer errors; he was developing into an independent learner and was able to self-regulate and monitor his own learning. Vygotsky's (2011) notion of scaffolding and explicit teaching was key in the elevation of this learner's reading skills. Equipped with these teaching strategies, he began to understand and use inference making. Six months later, through the process of asking guiding questions during his reading, he was able to improve his own reading practices. He developed the ability to assimilate and accommodate this new schemata (Piaget, 1981), which in turn led to an improvement in his intrinsic motivation and a better sense of equilibrium. By conducting this small research project, the teacher developed an understanding of how to scaffold a variety of thinking strategies to teach inference-making skills to a Grade 8 learner, purposefully encouraging his independence.

A final interpretation drawn from the results is that teacher guidance and step-by-step guidance are proven, within the parameters of this limited study, to be effective strategies for imparting new information to learners (McGee \& Johnson, 2003). During the IP, a direct link between explicit teaching and inference-making skills was established. These findings suggest that explicit teaching of comprehension skills, being socially engaged in answering deliberate higher-order questions, made it less stressful for the learner to participate in group comprehension activities. Being attentive to the learner's motivation through developing his self-efficacy contributed to the development of his self-confidence.

This study was limited to one male, aged 14 in Grade 8 and presenting as a struggling reader, over a period of only six weeks, with an emphasis on teaching inference skills only. The 
findings imply that when dealing with a struggling Grade 8 learner, who experienced a cognitive constraint, motivation and engagement assisted his reading achievement; particularly his understanding of inference skills. Future studies may include continuing the IP with students for a longer period and include on-grade readers to compare their pre- and post-scores. A further recommendation is to examine and extend the IP using intrinsic motivation and engagement to other subjects besides reading. An important consideration, emanating from this research, is the training of high school teachers. These teachers need to know how to teach basic reading skills such as fluency to low cognitive level learners; increasing towards more critical higher-order thinking skills with many opportunities to engage analytically with a variety of genres and texts.

\section{REFERENCES}

BANDURA, A. 1991. Social cognitive theory of self-regulation. Organizational Behaviour and Human Decision Processes, 50(2):248-287. Available from https://doi.org/10.1016/0749-5978(91)90022-L [2017, April 23].

BANDURA, A. 1993. Perceived self-efficacy in cognitive development and functioning. Educational Psychologist, 28(2):117-148.

BANDURA, A, C BARBARANELLI, GV CAPRARA \& C PASTORELLI. 1996. Multifaceted impact of self-efficacy beliefs on academic functioning. Child Development, 67: 1206-1222. 0009-3920/96/6703-0038\$01.00

BECK, S \& J CONDY. 2017. Instructional principles used to teach critical comprehensionskills to a Grade 4 learner. Reading \& Writing, 8(1). a149. Available from https://doi.org/10.4102/rw.v8i1.149 [2017, May 20].

BOAKYE, N. 2011. A multifaceted model for designing reading development programmes for L2 learners at tertiary level. Per Linguam, 27(2):114-132.

BOAKYE, N. 2015. The relationship between self-efficacy and reading proficiency of firstyear students: An exploratory study. Reading \& Writing, 6(1). Available from http://rw.org.za/index.php/rw/article/view/52 [2017, October 16].

CAPRARA, GV, C PASTORELLI, C REGALIA, E SCABINI \& A BANDURA. 2005. Impact of adolescents' filial self-efficacy on quality of family functioning and satisfaction. Journal of Research on Adolescence, 15(1): 71-97.

CARLSON, S, P VAN DEN BROEK, K MCMASTER, DN RAPP, CM BOHN-GETTLER, P KENDEOU \& M WHITE. 2014. Effects of comprehension skill of inference generation during reading. International Journal of Disability, Development and Education, 61(3): 258-274.

CLINTON, V 2015. Examining associations between reading motivation and inference generation beyond reading comprehension skill. Reading Psychology, 36(6): 473498.

CRESWELL, JW \& JD CRESWELL. 2018. Research design. Qualitative and quantitative and mixed methods approaches. London: Sage .

DEPARTMENT OF BASIC EDUCATION. 2011a. Curriculum and Assessment Policy Statement Grades 7-9 English Home Language. Pretoria: Government Printer.

DEPARTMENT OF BASIC EDUCATION. 2011b. Curriculum and Assessment Policy Statement Grades 10-12: Life Sciences. Pretoria: Government Printer.

DEPARTMENT OF BASIC EDUCATION. 2014. Report on the Annual National Assessment of 2014 Grades 1 to 6 \& 9. Pretoria: Government Printer. 
DONALD, D, S LAZARUS \& N MOOLLA. 2014. Educational psychology in social context. 5th ed. Oxford University Press.

GOWER, P. 2008. All schools need decent funding. Mail and Guardian, May 9-15.

GAMBRELL, LB. 2011. Seven rules of engagement: What's most important to know about motivation to read. The Reading Teacher, 65(3): 172-178.

GREEN, L. 2014. Schools as thinking communities. 1st ed. Pretoria: Van Schaik Publishers.

GUTHRIE, JT \& A WIGFIELD. 1999. How motivation fits into a science of reading. Scientific Studies of Reading, 3(3): 199-205.

GUTHRIE, JT. ed. 2008. Engaging adolescents in reading. California: Corwin Press.

GUTHRIE, JT \& SL KLAUDA. 2013. Handbook of individual differences in reading. New York: Routledge Publishers.

HENNING, E, W VAN RENSBURG \& B SMIT. 2004. Finding your way in qualitative research. Pretoria: Van Schaik Publishers.

HOWIE, S, C COMBRINCK, K ROUX, M TSHELE, G MOKOENA \& N MCLEOD PALANE. 2016. Progress in International Reading Literacy Study 2016: South African Children's Reading Achievement Summary Report. Pretoria: Centre for Evaluation and Assessment.

JOHNSON, P \& K KEIR. 2010. Catching readers before they fall. Portland: Stenhouse .

KLAPWIJK, NM. 2011. Reading strategy instruction in Grades 4 - 6: Towards a framework for implementation. Unpublished PhD dissertation: Stellenbosch University.

KLAUDA, SL \& J GUTHRIE. 2015. Comparing relations of motivation, engagement, and achievement among struggling and advanced adolescent readers. Read Writ, 28(2):239-269.

LURIA, AR. 1976. Cognitive development. Cambridge, MA: Harvard University Press.

LOGAN, S, E MEDFORD \& N HUGHES. 2011. The importance of intrinsic motivation for high and low ability readers' reading comprehension performance. Learning and Individual Differences, 21(1):124-128.

MAREE, K. (Ed). 2007. First steps in research. 1st ed. Pretoria: Van Schaik Publishers.

MARTELLA, R, J NELSON, RL MORGAN \& NE MARCHAND-MARTELLA. 2013. Understanding and interpreting educational research. New York: The Guilford Press.

MAYER, R. 2008. Learning and instruction. 2nd ed. New Jersey: Pearson Merrill Prentice Hall.

MCGEE, A \& H JOHNSON. 2003. The effect of inference training on skilled and less skilled comprehenders. Educational Psychology, 23(1):49-59.

MUDZIELWANA, N. 2013. Research-based teaching comprehension strategies: bridging the gap. Journal of Language Teaching and Research, 4(2). Available from http://www.academypublication.com/issues/past/jitr/vol04/02/12.pdf [2017, October 17].

OAKHILL, J, K CAIN \& C ELBRO. 2015. Understanding and teaching reading comprehension: A handbook. London: Taylor \& Francis Group.

PIAGET, J. 1981. Intelligence and affectivity: Their relationship during child development. California: Palo Alto Inc.

PILONIETA, P \& L MEDINA. 2009. Reciprocal teaching for the primary grades: 'We can to it, too!' The Reading Teacher, 63(2):120-129.

PRETORIUS, EJ \& NM KLAPWIJK. 2016. Reading comprehension in South African schools: Are teachers getting it, and getting it right? Per Linguam, 32(1):1-20.

PRETORIUS, EJ \& S CURRIN. 2010. Do the rich get richer and the poor poorer?: The effects of an intervention programme on reading in the home and school language in a high poverty multilingual context. International Journal of Educational 
Development, 30(1): 67-76.

PRITCHARD, A. 2009. Ways of learning: Learning theories and learning styles in the classroom. 2nd ed. New York: Routledge.

RAMAPHOSA, C. 2019. State of the nation address. 7 February.

ROBB, L. 2008. Differentiated reading instruction. New York: Scholastic Inc.

REYGAN, F, E WALTON \& R OSMAN. 2018. Assimilation and celebration?: Discourses of difference and the application of critical diversity literacy education. In E Walton \& R Osman, R. (Eds) Teacher education for diversity: Conversations from the global south. London: Routledge. 1-20.

RULE, P \& S LAND. 2017. Finding the plot in South African reading education. Reading \& Writing, 8(1), a121 Available from https://doi.org/10.4102/rw.v8i1.121 [2017, June 17].

SCHUMM, JS. 2006. Reading assessment and instruction for all learners. New York: The Guilford Press.

VYGOTSKY, LS. 2011. The dynamics of the schoolchild's mental development in relation to teaching and learning. Journal of Cognitive Education and Psychology, 10(2):198211. [Original publication: Vygotsky, LS. (1935). Dinamika umstvennogo razvitija schkol'nika v sviazi s obucheniem. In LV Zankov, Zh. I. Shif \& DB Elkonin (Eds), Umstevennoe razvitte detej v processe obuchenija (pp.33-52). Moscow-Leningrad: Uchepdigiz].

WADSWORTH, BJ. 1989. Piaget's theory of cognitive and affective development. London: Longman.

WORLD BANK REPORT. 2018. World Bank Report: Learning to realize education's promise. Washington: The World Bank. doi:10.1596/978-1-4648-1096-1.

ZIMMERMAN, L. 2014. Lessons learnt: Observations of Grade 4 reading comprehension teaching in South African schools across the Progress in International Reading Literacy Study (PIRLS) 2006 achievement spectrum. Reading \& Writing 5(1). Art.\#48, 9 pages. Available from http://dx.doi.org/10.4102/rw.v5i1.48 [2017, August 21].

ZIMMERMAN, L \& B. SMIT. 2014. Profiling classroom reading comprehension development practices from the PIRLS 2006 in South Africa. South African Journal of Education, 34(3). Available from http://www.sajournalofeducation.co.za/index.php/saje/article/view/962/453

[Accessed: 28 May 2017].

\section{BIOGRAPHICAL NOTES}

Yonela Palesa Moopelwa: At the time of conducting this research study she was an Honours student at CPUT. She teaches at Camps Bay High School where she was teaching Business Studies to Grades $10-12$ and EMS to Grades 8-9. It was during these experiences that she found her learners could not do comprehensions nor answer case study exam questions linking content to their real life situations.

Janet Condy is a professor at CPUT where she teachers on the undergraduate programme as well as the Inclusive Education specialisation subject to the Honours students. She supervisors Masters and Doctoral students. 